\title{
Globalization and innovation applying smart solutions
}

\author{
Ján Parobek ${ }^{1,{ }^{*}, \text { Erika Loučanová }}{ }^{1}$, Miriam Olšiaková ${ }^{1}$, Hubert Paluš ${ }^{1}$, Michal Dzian ${ }^{1}$ and \\ Anna Dovčíková ${ }^{1}$ \\ ${ }^{1}$ Technical University in Zvolen, T. G. Masaryka 24, 96001 Zvolen, Slovak Republic
}

\begin{abstract}
The global economic environment is closely connected with the continuous application of innovation reflecting global trends and market changes. Currently, substantial attention is focused on innovations presenting smart solutions. Their purpose rests in efficiency, economy, environmental friendliness, safety (including health). Moreover, they increase consumers' comfort. The packaging and its functions represents one of possibilities having considerable potential for sustainable development. It is related to the need to ensure that consumers perceive packaging in the context of sustainable development. The paper deals with consumers' attitudes to innovative (especially smart) packaging aspects. We focused on the attitude of consumers towards innovative packaging functions by using intelligent solutions and their overall perception of intelligent packaging with regard to their education and income in Slovakia. The survey results allow us identifying the main advantages of packaging functions for better understanding and consequently more effective communication in decision-making processes. The results point to the importance of packaging, especially in the protective, environmental, information and economic areas. The survey was applied as part of the global research and pointed out that consumers perceive this issue as unknown and new. This is the main reason why the results point to low consumer interest in smart packaging.
\end{abstract}

\section{Introduction}

Innovations have impact on the development of the economy at the national level. The importance of innovation do not only increase at the global level, but they also play a role in national competitiveness to gain a competitive advantage that consequently influences the country's success on the global market [1]. Important changes connected with phenomenon of globalization have taken place in all sectors of economies [2]. However, competitiveness and high growth rates in the economy are linked to investment in the innovation sector. At the same time, the economic environment is characterized by strong pressure from international competition. In particular, businesses need to solve how to obtain investment resources necessary for innovations. In an effort to increase the competitiveness in both national and global markets, companies often have limited access to new technologies or innovations [3]. By Krajňák \& Meier [4] globalization is essentially

\footnotetext{
*Corresponding author: parobek@tuzvo.sk
} 
influencing the whole economy. We can say that globalization and the technological revolution increase and emphasize the importance of knowledge and innovation activities. In addition, they have become a major competitive advantage for companies [5-7].

The success of a company in a global context determines the company's ability to respond promptly to change market conditions and its ability to meet customer needs. One way to achieve these goals is to innovate. It means to create new products and services that are genuine, different from other offers on the market and that meet market-relevant conditions. However, some approaches reject the concept of smart innovation. Cogliandro [8] belongs to the first authors dealing with the term of smart innovation. He explains smart innovation as a multidimensional process that is supported by a system of strategically balanced and creative problem solving. At the same time, smart innovations are an intuitive sense of the market and effort to succeed. Better implementation of many tasks, including management, motivation, finance decisions, and coordination of managerial responsibilities, results not only in intelligent innovation but also in the company's overall success. The purpose of smart innovation is to promote knowledge, provide and explain information on the subject's state and, if it is necessary, to manage it.

In Slovakia we do not normally meet with the term of intelligent innovation, even though its practical form on the market is quite usual. Loučanová et al. [9], regarding the basic definitions of innovation, characterizes smart innovation as "any autonomous change with a positive effect on a customer". The purpose of smart innovation is to bring more efficient, economical, healthier and safer solutions leading to increased customer comfort.

Traditionally, packaging is primarily used to protect the product against the deteriorative effects of the external environment, as a marketing tool to communicate with the consumer, to provide the consumer with a higher ability of use and time-saving convenience or to include products of different sizes and shapes, so it has a protective, communication, handling, information function) and moreover it is a tool for better product promotion. These packaging functions are expected by the customer. Higher packaging benefit lies in its effort to make better use and protection of the product (e.g. food), leading to overall customer satisfaction increase [10].

Global changes as well as overall progress acting in recent decades have an impact on the view of packaging materials and packaging techniques [11]. Creative unconventional thinking also results in packaging innovations. For example, active packaging makes it possible to change the state of packaged food, prolongs the shelf life of products, and even increases the safety and quality of the packaged food. Intelligent packaging can monitor the status of packaged food. In addition, it provides clear information on product quality during transport and storage [12].

Over time, there has been a change in consumer perceptions and attitudes towards packaging products. Previous studies defined packaging as an essential part of the product. Modern studies come with a change in the characterization of the packaging and point to a change in its perception, where the packaging is seen as an attractive part of the product.

The packaging still creates the first impression of the product when buying. The packaging should be mainly user-friendly and functional. The packaging has the following expectations: it should be easy to use, provide relevant information and be storable [13].

Many studies have focused on research of consumer perception of packaging, its impact on purchasing intentions and consumer attitudes [14-16].

Consumer attitudes toward active and intelligent packaging differ in various countries. Brennan and Crandison [17] state that active packaging is generally accepted in the US, Australia, Japan, but less in European countries. However, some types of smart packaging are more accepted in European countries. The reason of these differences is not clear, but it may be partly caused by differences in culture or to a lack of understanding of the benefits and advantages of these types of packaging. 
The research focuses on the perception of innovative packaging functions within intelligent solutions as well as finding answers about smart packaging regarding to education and income of consumers.

\section{Methods}

An essential element of the research we applied the marketing survey at the beginning of 2019. It focused on the individual functions of smart packaging and getting answers to questions about smart packaging with regarding the education and income of Slovak consumers.

The survey sample consisted of 100 respondents. The data obtained by the research were processed and then analyzed. Within the statistical analyzes we focused on interdependencies between variables (education and income) and respondents' attitudes to individual selected areas of smart packaging.

The influence of these categorical variables (education, income) on individual responses was analyzed by the Chi square test with the probability $95 \%$. This test allows finding a statistically significant effect between variables. Chi square test says that the expected answers are independent of variables, in our case, income and education.

If the null hypothesis is rejected ( $p<0.05)$, there is a significant difference between the actual and expected frequency. It means that there is a statistically significant relationship between independent variables and respondents' answers $[18,19]$.

The conclusions to the problem were processed on the basis of the analyzed data using the inductive-deductive method.

\section{Results and discussion}

The research results present the preferred functions of smart packaging in the Slovak Republic (Figure 1). For Slovak respondents, according to the analyzed data the most important functions of packaging are economic and ecological functions. On the contrary, the least important function is the promotional function, but it is not negligible in the consumer's decision making, whereas the value is higher than average (value $=3.9$ ).

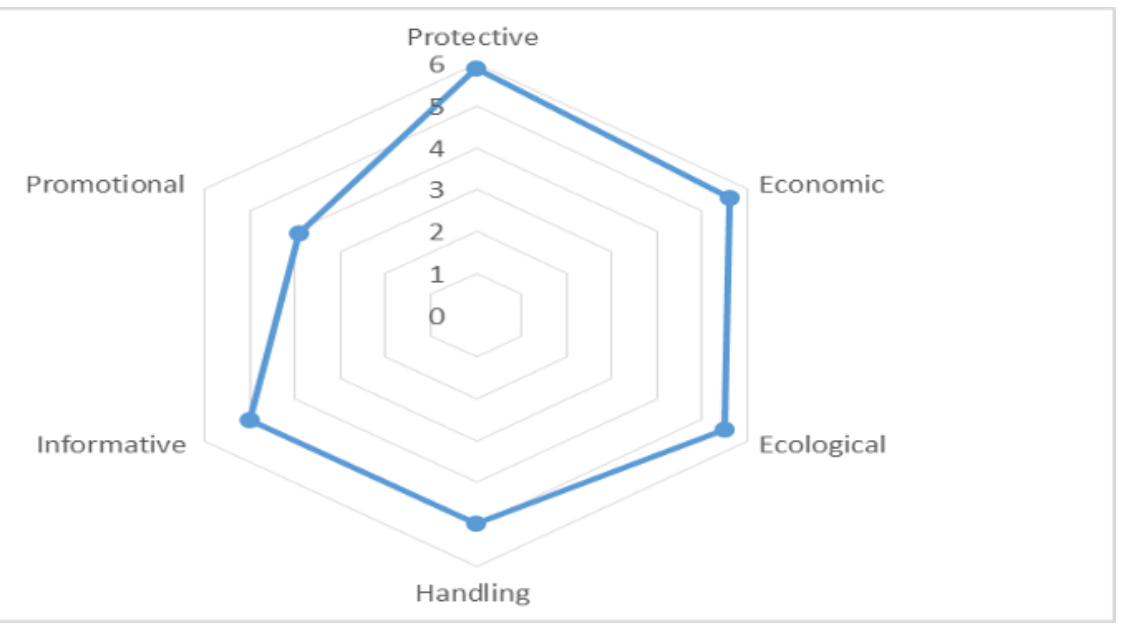

Fig. 1. Average value of understanding of different smart packaging functions.

The results were based on a statistical analysis of the interdependence between variables (income and education) and the individual areas examined by chi square test. Income as an 
independent categorical variable represents parameter with less statistical significance compared to education. The statistical significant impact of education is in attitudes to utilisation of paper packaging or antioxidant or antimicrobial films $(p=0.009)$. Except mentioned, the issue of packaging functions in relation to product promotion (specifically if they are appropriate for a given product type) is also statistically significant $(\mathrm{p}=0.047)$. In other researched areas the Chi square test confirmed independency between attitudes and income or education ( $\mathrm{p}$ value is higher than 0.05 ) with $95 \%$ of probability.

When evaluating responses from the education point of view. We found out that education has a statistically significant impact on the perception of suitability and promotional aspects of smart packaging, as well as its informative function, that are finally reflected in purchasing decisions of respondents $(\mathrm{p}=0.015$ and $\mathrm{p}=0.013)$.

In addition, education have significant role on understanding of advertising-related packaging functions $(\mathrm{p}=0.016)$, which contain information influencing consumer's decision about a product ( $\mathrm{p}$ value $=0.013$ )

Moreover, Chi square test confirmed a statistical significant relation to information on content of a product $(\mathrm{p}=0.043)$, as well as preferences of traditional packaging $(\mathrm{p}=0.039)$ and packaging containing pads absorbing liquid waste and improving protection of a product $(\mathrm{p}=0.037)$. The chi square tests consider the other researched parameters as statistically insignificant.

In the research we focused on individual functions of packaging. Besides above mentioned promotional and information function of the packaging, we also examined the attitude of respondents to the ecological function of packaging. In the ranking it was on the second place. Attitudes of respondents are similar within individual educational and income groups.

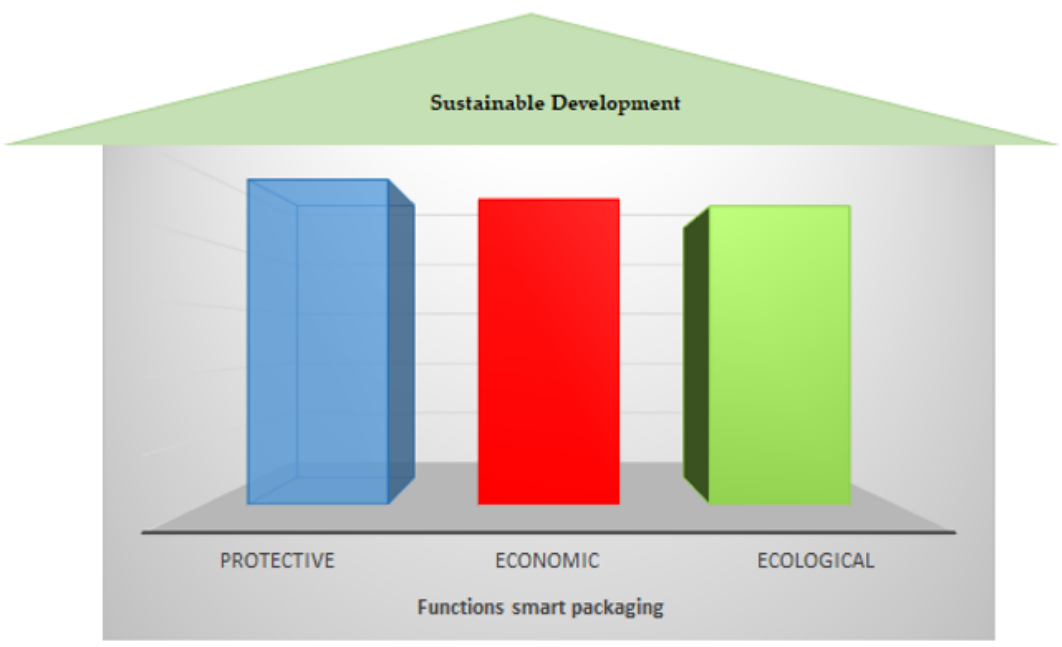

Fig. 2. Values of intelligent packaging functions in terms of values of sustainability development.

Based on the evaluation of the results, we can conclude that Slovak consumers think responsibly, because they prefer the ecological, economic and protective function of packaging as the most important. Given functions are considered as social and therefore Slovak consumers can be considered as socially responsible (Figure 2). 
If sustainable development is based on the principles of corporate social responsibility $[20,21]$ then smart packaging supports sustainable development, because Slovak respondents prefer smart packaging based on this principle.

\section{Conclusions}

Nowadays, packaging is a significant tool that contributes to sustainable development through its functions. Consumers need to understand and accept packaging features and thus influence on the sustainable development.

Thanks to the research, we can identify the main advantages of each packaging function, which subsequently will improve understanding and communication in decisionmaking processes for companies. Based on the individual answers of the respondents we can conclude that the most important are the protective, ecological, informative and economic functions of the packaging.

On the contrary, the respondent considers the promotion function of the packaging to be the least important. At the same time, respondents are not willing to accept the price increase because of packaging innovation.

Loučanová et al. [9] notes that requirements for a new approach taking into account all essential packaging functions (e. g. handling, preservative, informative, economic, environmental, promotional and ecological) have been established.

Respondents in all age categories required ecological innovation in packaging. The older generation requires especially innovation of the handling function of packaging. It has a low innovation status, but a very significant impact on their purchasing decision making of consumers.

The customers perceive the above mentioned issue to be unknown and new. This is the reason why the results show the low interest in individual smart packaging innovation. On the other hand, the lack of experience, information and knowledge of innovative packaging reflects the unwillingness of the final customers to accept the higher price increase.

This paper is an output of the science project number 1/0674/19 "Proposal of a model for the ecoinnovation integration into the innovation process of companies in Slovakia in order to increase their performance" and grant number 1/0666/19 "Determination of the development of a wood-based bioeconomy" and European Cooperation in the field of Scientific and Technical Research - COST, COST Action FP1405 "Active and Intelligent Fibre-Based Packaging - Innovation and Market Introduction (ACTINPAK)".

\section{References}

1. E. Gregorová, V. Dengov, Význam inovácií z aspektu inovačnej stratégie. Globalizácia a jej sociálno ekonomické aspekty'14. 7 (2014)

2. P. Bielik, D. Hupková, The Impact of Globalization on Agricultural Policy. Ekonomika i Organizacja Gospodarki Żywnościowej, Zeszyty Naukowe. 68. 6 (2008)

3. L. Paškrtová, Pôsobenie malých a stredných podnikov na Slovensku v meniacej sa globálnej ekonomike. Globalizácia a jej sociálno ekonomické aspekty'14. 9 (2014)

4. M. Krajňák, V. Meier, Application of a Selected Method of Multi-criteria Decision when Preparing Financial Statements according to IFRS and Czech Accounting Standards. Globalization and its socio-economic consequences 2016.7 (2016)

5. K. Gubová, P. Richnák, Development and use of intangible assets in the conditions of globalization. 16th International Scientific Conference Globalization and Its SocioEconomic Consequences. 8 (2016) 
6. M. Kováčiková, K. Repková-Štofková, Impact of globalization on access to process businesses management. 16th International Scientific Conference Globalization and Its Socio-Economic Consequences. 9 (2016)

7. S. Štofko, V. Šoltés, Z. Štofková, Options of using the integrated management system. Production Management and Engineering Sciences Production Management and Engineering Sciences. 6 (2015)

8. J.A. Cogliandro, Intelligent Innovation: Four Steps to Achieving a Competitive Edge. (Ross Publishing, 2007)

9. E. Loučanová, J. Parobek, M. Kalamárová, H. Paluš, H. Mat'ová, K. Repková Štofková, Innovation activities in micro and small companies in Slovakia. Globalization and its socio-economic consequences 2015. 4 (2015)

10. K.L. Yam, P.T. Takhistov, J. Miltz, Intelligent Packaging: Concepts and Applications. Journal of Food Science. 70, 10 (2005)

11. V. Kaputa, M. Triznová, M., H. Mat'ová, Is paper still attractive for generation Y? Marketing identity : online rules - part II. 8 (2017)

12. R. Ahvenainen. Novel food packaging techniques. (Woodhead Publishing Limited, 2000)

13. M. Löfgren, L. Witell, Kano's Theory of Attractive Quality and Packaging. The Quality Management Journal, 12, 14 (2005).

14. H. Kauppinen-Räisänen, H.T. Luomala, Exploring consumers' product-specific colour meanings. Qualitative Market Research. 13, 12 (2010).

15. J. Parobek, H. Paluš, M. Kalamárová, E. Loučanová, M. Šupín, A. Križanová, K.R. Štofková, Energy utilization of renewable resources in the European union -cluster analysis approach. BioResources. 11, 12 (2016).

16. G. Prakash, P. Pathak, Intention to buy eco-friendly packaged products among young consumers of India: A study on developing nation. Journal of Cleaner Production, 141, 9 (2017)

17. J.C. Brennan, A.S. Crandison, Food processing handbook (Wiley, 2011)

18. M. Rimarčík, Štatistika pre prax (Marián Rimarčík, 2007)

19. V. Kaputa, H. Paluš, S. Blažková, M. Šupín. Barometer of public opinion in attitudes towards wood products: a methodological approach. Innovation as the source of values in the forestry, wood processing and furniture manufacturing. 4 (2013)

20. M. Olšiaková, M., E. Loučanová, E, M. Kalamárová, Application of new trends of marketing communication as a competitiveness tool in furniture industry. 10th Annual International Scientific Conference on More Wood, Better Management, Increasing Effectiveness: Setting Points and Perspectives Location. 6 (2017)

21. E. Loučanová, M. Kalamárová, J. Parobek, Konkurencieschopnost' produktov dreva z pohl'adu použitého materiálu. Acta Facultatis Xylologiae Zvolen. 57, 9 (2015) 